\title{
СЕЙСМОГЕОЛОГИЧЕСКАЯ И СТРУКТУРНО- ТЕКТОНИЧЕСКАЯ ХАРАКТЕРИСТИКА КОНТИНЕНТАЛЬНОЙ ОКРАИНЫ СИБИРСКОЙ ПЛАТФОРМЫ (Хатангско-Ленское междуречье)
}

Конторович В. А., Конторович А. Э., Калинин А. Ю., Калинина Л. М., Лапковский В. В., Лунев Б. В., Моисеев С. А., Соловьев С. А.

\begin{abstract}
Аннотация
Рассмотрены сейсмогеологические и структурно-тектонические особенности строения верхнепротерозойско-палеозойских и мезозойских осадочных комплексов в арктических регионах Сибирской платформы.
\end{abstract}

По результатам глубокого бурения проанализировано геологическое строение исследуемой территории построены опорные разрезы верхнепротерозойско-палеозойских отложений АнабароХатангской и Лено-Анабарской нефтегазоносных областей (НГО).

Анализ геолого-геофизических материалов показал, что на континентальной окраине Сибирской платформы развит осадочный бассейн мощностью до 14-16 км, в разрезе которого выделяется 5 регионально-развитых сейсмогеологических мегакомплексов: рифейский, вендский, нижнесреднепалеозойский, пермский и мезозойский.

По результатам комплексной интерпретации материалов сейсморазведки МОГТ и глубокого бурения выполнен структурно-тектонический анализ, построены структурные карты по всем реперным стратиграфическим уровням, сделан вывод о подобии структурных планов кровли рифея и вышележащих осадочных комплексов. С использованием структурной карты по кровле перми построена отвечающая современной стадии изученности тектоническая карта исследуемого региона.

Приведены результаты численного моделирования процессов формирования соляных диапиров, рассмотрены типы антиклинальных структур - потенциальных нефтегазоперспективных объектов.

\section{Ключевые слова:}

Сибирская платформа, Анабаро-Хатангская НГО, Лено-Анабарская НГО, осадочный бассейн, сейсмогеологический комплекс, сейсмический горизонт, структурная карта, тектоника, поднятие, соляные купола, диапиры. 
УДК: 550.834.05, 553.98

СЕЙСМОГЕОЛОГИЧЕСКАЯ И СТРУКТУРНО-ТЕКТОНИЧЕСКАЯ ХАРАКТЕРИСТИКА КОНТИНЕНТАЛЬНОЙ ОКРАИНЫ СИБИРСКОЙ ПЛАТФОРМЫ (Хатангско-Ленское междуречье)

\section{Конторович В.А., Конторович А.Э, Калинин А.Ю., Калинина Л.М., Лапковский В.В., Лунев Б.Л., Моисеев С.А., Соловьев М.В. \\ Институт нефтегазовой геологии и геофизики им. А.А. Трофимука СО РАН, 630090, Новосибирск, просп. Академика Коптюга, 3, Россия}

\section{ОБЪЕКТ ИССЛЕДОВАНИЙ}

На современном этапе одной из важнейших задач нефтяной геологии и геофизики является изучение геологического строения и оценка перспектив нефтегазоносности Арктических регионов России и шельфов северных морей.

Настоящая работа посвящена анализу геолого-геофизических материалов по Арктическим регионам Сибирской платформы, расположенным на побережье моря Лаптевых в междуречье Хатанги и Лены (Хатангско-Ленский регион). Исследуемая территория охватывает Анабаро-Хатангскую, Лено-Анабарскую нефтегазоносные области (НГО) и северную часть Анабарской НГО Лено-Тунгусской нефтегазоносной провинции (НГП), а также северную часть Предверхоянской НГО Лено-Вилюйской НГП [Геология нефти и газа, 1981; Старосельцев, 2012] (рис. 1).

В административном отношении исследуемая территория находится на северовостоке Красноярского края, северо-западе республики Саха (Якутия) и включает акваторию Хатангского залива моря Лаптевых.

Рассматриваемый регион являлся объектом систематических целенаправленных нефтепоисковых исследований в 30-80-х гг. прошлого столетия. В те годы на этой территории была отработана сеть сейсмических профилей, выполнены гравимагниторазведочные работы, пробурены глубокие скважины, выполнены многочисленные научные и аналитические исследования.

Новейший этап изучения северных районов Сибирской платформы начался в XXI веке, когда в акватории и на побережье Хатангского залива, а также в южных и центральных районах Хатангско-Ленского региона была отработана сеть современных региональных сейсморазведочных профилей МОГТ и пробурена серия глубоких колонковых скважин. В 2017 г. в акватории Хатангского залива в непосредственной близости от п-ва Хара-Тумус компанией ПАО «Роснефть» открыто первое в этом регионе 
поставленное на Государственный баланс нефтяное месторождений - ЦентральноОльгинское.

\section{ГЕОЛОГО-ГЕОФИЗИЧЕСКАЯ ИЗУЧЕННОСТЬ}

Сейсморазведка МОГТ. На севере Сибирской платформы сейсморазведочные работы МОГТ проводились в 80-х - 90-х годах прошлого столетия организациями Якутскгеофизика и Таймыргеофизика. Работы были выполнены по традиционной для того периода методике МОГТ с 12-кратным перекрытием. Работы носили как региональный, так и площадной характер. Относительно плотные сетки профилей были отработаны на Усть-Оленекском и Прончищевском поднятиях, которые находятся в северной части исследуемого региона, на побережье моря Лаптевых и на ряде площадей АнабароХатангской НГО.

В 2008-2015 гг. в рамках Федеральной программы в исследуемом регионе была отработана сеть современных региональных сейсмических профилей повышенной кратности. Профили были размещены, главным образом, в Хатангском заливе и на прилегающих территориях, в южной части Лено-Анабарской НГО и на мелководье моря Лаптевых в транзитной зоне. Серия профилей в широтном направлении пересекает Анабаро-Хатангскую и Лено-Анабарскую НГО.

В целом, в настоящее время на исследуемой территории отработано 13630 км сейсмических профилей МОГТ, в том числе 6570 км профилей 80-х годов и 7060 км современных профилей XXI века (см. рис.1). Средняя плотность сейсмических наблюдений составляет 0.095 км/км².

В настоящее время в Анабаро-Хатангской и Лено-Анабарской НГО пробурено 60 глубоких скважин (в Анабаро-Хатангской НГО - 54, в Лено-Анабарской НГО - 6), которые позволяют надежно стратифицировать отражающие сейсмические горизонты и сейсмогеологические комплексы.

\section{ГЕОЛОГИЧЕСКОЕ СТРОЕНИЕ ХАТАНГСКО-ЛЕНСКОГО РЕГИОНА}

Вскрытый глубокими скважинами геологический разрез Хатангско-Ленского региона представлен образованиями архейско-протерозойского фундамента и верхнепротерозойско-фанерозойского осадочного чехла, который, в свою очередь, сложен отложениями рифея, венда, кембрия, ордовика-силура, девона-карбона, перми, триаса, юры и мела. Опорные геологические разрезы верхнепротерозойско-палеозойских отложений приведены на рис. 2, 3.

Архейско-протерозойский фундамент. На севере Сибирской платформы верхнепротерозойско-фанерозойские отложения осадочного чехла залегают на архейско- 
протерозойском фундаменте, который представлен глубоко метаморфизованными кристаллическими сланцами, гнейсами, кварцсодержащими и магматическими породами.

В Хатангско-Ленском регионе эти образования вскрыты скважиной Костроминская № 1, расположенной в пределах крупного выступа фундамента, сложенного гранитами, гнейсами и долеритами.

Рифей. На исследуемой территории наиболее полный разрез рифея вскрыт в скважине Бурская № 3410, где его мощность составляет 1392 м. В этой зоне рифейские отложения представлены переслаивающимися 400-500 метровыми пачками доломитов и терригенных пород.

Венд. В Анабаро-Хатангской и Лено-Анабарской НГО вендские отложения с несогласием залегают на рифее и сложены карбонатами. На востоке Хатанга-Ленского региона в верхней части венда - низах кембрия залегает толща терригенных пород кессюсинской (тюсерской) свиты, которую традиционно выделяют в качестве нефтепроизводящей [Грамберг, 1958].

Кембрий на континентальной окраине Сибирской платформы представлен известняками и доломитами с прослоями ангидритов. В Анабаро-Хатагской НГО Максимальная мощность кембрия на Южно-Соулемской и Северо-Соулемской площадях составляет, соответственно, 764 и 800 м. В Лено-Анабарской НГО кембрийские отложения представлены, главным образом, доломитами; мощность кембрия в скважинах Бурская № 3410, Хастахская № 930 и Чарчыкская № 1, расположенных в южной части НГО, где кембрий залегает на венде составляет, соответственно, 844, 965 и 955 м.

Ордовик-силур на большей части исследуемой территории в разрезе отсутствует и, на кембрии несогласно залегают отложения девона-перми. Исключение составляет крайний север Лено-Анабарской НГО, где в скважине Усть-Оленекская № 2370, расположенной на побережье моря Лаптевых вскрыта 475-метровая толща карбонатов ордовикского (ордовик-силурийского-?) возраста [Граусман, 1995]. К юго-западу от рассматриваемого региона в скважине Ледянская № 1, пробуренной в Енисей-Хатангском региональном прогибе, мощность ордовика-силура достигает 1035 м.

Девон-карбон вскрыт скважинами на востоке Хатангско-Ленского региона в Анабаро-Хатангской НГО и размыт в Лено-Анабарском междуречье. Характерной особенностью Анабаро-Хатангской НГО является наличие в низах девона солеродного бассейна и связанной с ним системой соляных куполов. Соли выходят на поверхность на полуострове Юрюнг-Тумус (Хара-Тумус), а также на Нордвикской и Кожевниковской площадях. В пробуренных на крыльях Нордвикского и Кожевниковского соляных куполов скважинах подошва девона не вскрыта; вскрытая мощность составляет 69-596 м. 
Девонский солеродный бассейн имел небольшие размеры и узкой полосой в северовосточном направлении пересекал территорию Анабаро-Хатангской седловины. В пластовых условиях на рассматриваемой территории соли не вскрыты и согласно результатов численного эксперимента все они «выдавлены» в соляные купола, с которыми связано большинство антиклинальных структур Анабаро-Хатангской НГО [Конторович и др., 2019б]. В целом мощность отложений девона-карбона, получившего ограниченное распространение на исследуемой территории, изменяется в диапазоне от 0 до 1100 м на склонах соляных куполов.

Пермь. Пермские отложения в Анабаро-Хатангской НГО представлены тустахской, нижнекожевниковской, верхнекожевниковской и мисайлапской свитами, сложенными терригенными породами - переслаивающимися песчаниками, алевролитами и аргиллитами с прослоями углей и углистых аргиллитов. Аналогами этих отложений в Лено-Анабарской НГО являются нижнепермская джаргалахская свита и верхнепермская бурская толща.

По данным бурения толщина пермских отложений в исследуемом регионе изменяется в диапазоне от 0 м в скважине Нордвикская № 48, пробуренной на соляном куполе, до 2370 м на Усть-Оленекской площади. По результатам интерпретации сейсмических материалов в Хатанга-Ленском регионе мощность перми регионально увеличивается в северном направлении и в наиболее погруженной части Хатангского залива толщина этих отложений достигает 3000 м. В разрезе перми выделяются обогащенные органическим веществом глинистые пачки нижнекожевниковской и тустахской свит, которые являются нефтепроизводящими [Каширцев, 2003, 2013].

Мезозой. Пермь с несогласием перекрыта мезозойскими терригенными отложениями триаса, юры и мела. Мезозойский комплекс пород также сложен переслаивающимися песчаниками, алевролитами и аргиллитами. Эти отложения размыты в южной части исследуемого региона и отсутствуют в разрезах скважин Костроминская № 1 и Бурская № 3410. Максимальная мощность мезозоя зафиксирована в скважине Кожевниковская № 14, где суммарная толщина триасовых, юрских и меловых отложений составляет 1492 м.

\section{СЕЙСМОСТРАТИГРАФИЧЕСКАЯ ХАРАКТЕРИСТИКА}

Анализ сейсмических данных показа, что на крайнем севере Сибирской платформы развит неопротерозойско-мезозойский осадочный бассейн, в пределах которого мощность платформенных отложений достигает 14-16 км [Афанасенков и др., 2016; Конторович и др., 2013, 2014, 2019б]. 
Анализ временных сейсмических разрезов и данных бурения позволяет выделить в осадочном чехле этого региона 5 регионально-развитых сейсмогеологических мегакомплексов: рифейский, вендский, нижне-среднепалеозойский, верхнепалеозойский (пермский) и мезозойский, которые в кровле и подошве контролируются сейсмическими реперами (табл. 1, рис. 4).

Приуроченный к подошве осадочного чехла отражающий горизонт $\mathrm{R}_{0}$ отделяет на временных разрезах высокоамплитудные волновые поля, подчеркивающие платформенный облик рифейских осадков, от пород архейско-протерозойского фундамента, характеризующегося слабоамплитудным хаотическим рисунком сейсмической записи.

Среди отражающих горизонтов чехла наилучшим качеством прослеживания и наибольшей энергетической выразительностью обладает приуроченный к подошве перми отражающий горизонт $\mathrm{P}_{0}$, который одновременно контролирует крупный предпермский (раннепермский) перерыв в осадконакоплении. В исследуемом регионе этот перерыв четко фиксируется на временных разрезах, и в различных частях региона нижележащие рифейнижнепалеозойские отражающие горизонты срезаются этой эрозионной поверхностью.

Рифейский сейсмогеологический мегакомплекс в подошве контролируется отражающим горизонтом $\mathrm{R}_{0}$, в кровле - горизонтом RR. Приуроченный к подошве рифейского мегакомплекса отражающий горизонт $\mathrm{R}_{0}$ отделяет на временных разрезах высокоамплитудные рифейские волновые поля, подчеркивающие платформенный облик осадков, от пород архейско-протерозойского фундамента, характеризующегося хаотическим рисунком сейсмической записи.

В наиболее полных разрезах рифея исследуемого региона мощность платформенных отложений достигает 8-10 км, и внутри него выделяется 3-4 согласно залегающих сейсмогеологических комплекса, к кровлям которых приурочены энергетическивыраженные отражающие сейсмические горизонты. В южной части исследуемого региона в направлении Анабарского свода более молодые рифейские сейсмокомплексы последовательно срезаются эрозионной поверхноостью и под палеозой выходят более древние рифейские осадочные толщи. В пределах наиболее приподнятых участков и контрастных выступов мощность «срезанных» эрозией рифейских платформенных отложений достигает 6-7 км (см. рис. 4).

Вендский сейсмогеологический мегакомплекс на временных разрезах контролируется отражающим горизонтом $\mathrm{PZ}_{0}$ в кровле, RR - в подошве. В АнабароХатангской НГО венд сложен преимущественно доломитами. В Лено-Анабарской НГО эта толща пород имеет двучленное строение: нижняя часть комплекса представлена 
карбонатами и имеет мощность 650-700 м, выше по разрезу залегает венднижнекембрийская толща терригенных пород, выделенная в составе кессюсинской свиты. Залегающая в верхах венда - низах кембрия кессюсинская свита имеет мощность 200300 м, обогащена органическим веществом и рассматривается в качестве нефтепроизводящей [Грамберг, 1958].

Принципиальное отличие вендского мегакомплекса от вышележащих отложений заключается в том, что он не срезается эрозионной поверхностью, а выклинивается на приподнятые блоки рифея (см. рис.4, рис. 5).

Нижне-среднепалеозойский сейсмогеологический мегакомплекс в кровле контролируется отражающим горизонтом $\mathrm{P}_{0}$, к подошве комплекса в зоне развития венда приурочен отражающий горизонт $\mathrm{PZ}_{0}$. На территориях, где вендские отложения выклиниваются на выступы рифея, подошва нижне-среднепалеозойсих отложений контролируется горизонтом RR. Отражающие горизонты $\mathrm{PZ}_{0}$ и $\mathrm{RR}$, формирующиеся, соответственно, на кровлях венда и рифея, характеризуются высоким энергетическим уровнем и надежно прослеживаются на временных разрезах.

В восточной и западной частях Хатангско-Ленского региона разрез нижнесреднепалеозойских отложений существенно отличается.

В Лено-Анабарской НГО нижне-среднепалеозойский мегакомплекс пород представлен преимущественно карбонатами кембрия, которые на большей части территории с несогласием перекрыты терригенными пермскими отложениями. Ордовиксилур на большей части НГО в разрезе отсутствует и вскрыт только на Усть-Оленекской площади, расположенной на побережье моря Лаптевых [Граусман, 1995].

На юго-востоке Лено-Анабарской НГО на временных разрезах внутри нижнесреднепалеозойского мегакомплекса выделяется два устойчивых отражающих горизонта $\mathrm{K}_{1}$ и $\mathrm{K}_{2}$, формирующихся на геологических границах, приуроченных, соответственно, к базальной и верхней частям кембрийского разреза (см. рис. 5).

На временных разрезах этого региона внутри сейсмокомплекса четко фиксируется косослоистый (клиноформный) рисунок сейсмической записи. В юго-западном направлении, в направлении Анабарского свода горизонты $\mathrm{K}_{1}$ и $\mathrm{K}_{2}$ погружаются, формируя клиноформы южного падения (см. рис. 5).

В Анабаро-Хатангской НГО в основании нижне-среднепалеозойского мегакомплекса залегает кембрийская преимущественно карбонатная толща, которая с перерывом перекрыта известняками девона-карбона, либо терригенными толщами перми. Особенностью геологического строения среднепалеозойских отложений АнабароХатангской седловины является наличие в разрезе раннего-среднего девона соленосной 
толщи и серии соляных куполов [Калинко, 1959; Косыгин, 1960; Соляная тектоника, 1973; Старосельцев, Дивина, 2012]. Расположенный на этой территории Нордвикский диапир прорывает толщи верхнего девона, карбона, перми и мезозоя и выходит на дневную поверхность, девонские соли также выходят на поверхность на п-ве Юрюнг-Тумус. На Кожевниковской площади и ряде других объектов получили развитие погребенные, не выходящие на поверхность соляные купола - криптодиапиры, затухающие в перми и мезозое.

На временных разрезах соляные купола характеризуются столбообразной расфазировкой и падением амплитудно-энергетических характеристик волновых полей хаотическим рисунком сейсмической записи (рис. 6).

Пермский сейсмогеологический мегакомплекс на временных разрезах контролируется отражающими горизонтами $\mathrm{T}_{0}$ в кровле и $\mathrm{P}_{0}$ - в подошве. Отражающий горизонт $\mathrm{P}_{0}$ распространен практически на всей исследуемой территории и отсутствует только на юговостоке, где на дневную поверхность выходит кембрий. Отражающий горизонт $\mathrm{P}_{0}$, контролирующий подошву пермского комплекса, одновременно приурочен к крупному предпермскому (раннепермскому) перерыву в осадконакоплении.

В Лено-Анабарской НГО этот перерыв четко фиксируется на временных разрезах, и в различных частях региона нижележащие рифей-кембрийские отражающие горизонты срезаются этой эрозионной поверхностью [Конторович и др, 2013, 2014, 2019А] (см. рис. 4).

Внутри пермского мегакомплекса выделяется два относительно устойчивых отражающих горизонта, приуроченных к кровлям нижнекожевниковской и тустахской свит. По аналогии с мезозоем мощность пермских отложений также регионально увеличивается в северном направлении; максимальные толщины, достигающие 25003000 м, фиксируются в северной части Хатангского залива.

Мезозойский сейсмогеологический мегакомплекс залегает в верхней части осадочного чехла, включает терригенные отложения триаса, юры и мела. На временных разрезах мезозойский сейсмокомплекс в подошве контролируется отражающим горизонтом $\mathrm{T}_{0}$, в кровле дневной поверхностью. На севере Сибирской платформы мощность мезозоя регионально уменьшается в южном направлении с 3000 м до 0 м.

Сокращение толщин этих отложений также происходит над контрастными антиклинальными структурами - Прончищевским, Аллаханским и Усть-Оленекским поднятиями, расположенными в северной прибрежной части Лено-Анабарской НГО и над Нордвикским, Западно-Нордвикским, Ольгинским, Кожевниковским и др. поднятиями Анабаро-Хатангской НГО. 
На севере Лено-Анабарского прогиба и в Анабаро-Хатангской мегаседловине, на участках, где толщина мезозоя превышает 1000 м, внутри этого мегакомплекса выделяется два отражающих горизонта $\mathrm{J}_{0}$ и $\mathrm{K}_{0}$, приуроченных к подошвам юры и мела соответственно.

\section{СТРУКТУРНО-ТЕКТОНИЧЕСКАЯ ХАРАКТЕРИСТИКА}

В рамках проведенных исследований была выполнена комплексная интерпретация сейсмических материалов и данных бурение и осуществлено построение структурных карт по кровлям рифейского, вендского, нижне-среднепалеозойского, пермского и триасюрского сейсмогеологических комплексов, которые позволили существенно уточнить структурно-тектоническое строение Хатанга-Ленского региона.

Анализ результатов структурных построений показал, что в региональном и зональном плане поверхности всех стратиграфических уровней в значительной мере подобны (рис. 7). В пределах рассматриваемого региона неопротерозойско-палеозойские и мезозойские отражающие горизонты регионально погружаются в северном направлении.

Наименьшие глубины фиксируются в южной части исследуемой территории, в пределах Северо-Анабарской мегамоноклизы, и на северо-востоке, в Притаймырской зоне. Наиболее глубоко неопротерозойско-фанерозойские отложения залегают в осевых частях крупных депрессий - в Лаптевской, Лено-Анабарской синеклизах и в Енисей-Хатангском региональном прогибе.

Структурная карта по кровле одного из наиболее перспективных в отношении нефтегазоносности пермского комплекса послужила основой для построения тектонической схемы Хатангско-Ленского региона.

В практике нефтяной геологии под тектоническими картами, которые традиционно используются при нефтегазогеологическом районировании, понимают генерализованные структурные карты, на которых выделяются положительные, отрицательные и промежуточные тектонические элементы различных порядков.

В настоящей работе при выделении структур различных порядков была использована классификация платформенных тектонических элементов, принятая Межведомственным совещанием, прошедшем в Ленинграде в 1963 году, и несколько уточненная и дополненная специалистами ИНГГ СО РАН [Конторович и др., 2004].

Остановимся более подробно на структурно-тектонической характеристике этого стратиграфического уровня (рис. 8).

Кровля перми. В пределах рассматриваемого региона пермские отложения залегают на глубинах до 3200 м, при этом рельеф кровли перми регионально погружается в северном направлении. Наименьшие глубины фиксируются в южной части исследуемой 
территории, в пределах Северо-Анабарской мегамоноклизы и на северо-востоке, в Притаймырской зоне.

На северном склоне Анабарской антеклизы пермские отложения сначала выходят на дневную поверхность, а затем срезаются эрозионной поверхностью. На структурной и тектонической картах по кровле перми граница отсутствия этих отложений выделена по Геологической карте России (2004).

Анализ структурных построений показал, что наибольшие глубины залегания пермских отложений фиксируются в Бегичевской мегавпадине, расположенной на северозападе исследуемого региона в акватории моря Лаптевых и в осевых частях крупных депрессий - в Хетском мегапрогибе, осложняющем Енисей-Хатангский региональный прогиб, Юрянг-Хаянской и Таймылырской мегавпадинах, которые расположены в западной и восточной частях Лено-Анабарской синеклизы.

В северной части исследуемой территории расположена Южно-Лаптевская синеклиза, западная часть которой осложнена Бегичевской мегавпадиной. В пределах исследуемой территории площадь Южно-Лаптевской синеклизы, оконтуренной на абсолютной отметке -1000 м, составляет 28625 км².

Бегичевская мегавпадина раскрывается в северном направлении за пределы исследуемой территории. В рельефе кровли перми депрессия контролируется изогипсой -1200 м и имеет амплитуду 1250 м. Мегавпадина осложнена тремя замкнутыми впадинами, прогибом и одной положительной структурой II порядка - СевероБегичевским мезоподнятием. Мезоподнятие контролируется изогипсой -1500 м, имеет

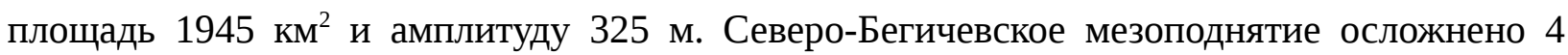
локальными структурами, наиболее крупными из которых являются Бегичевское (№12) и Северо-Бегичевское (№7) локальные поднятия. Площади этих структур составляют,

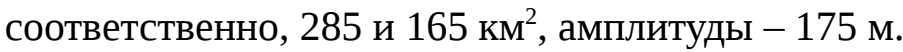

К югу от Бегичевской мегавпадины расположен вытянутый в широтном направлении узкий линейный Сопочный мезовал, отделяющий мегавпадину от расположенного к югу Енисей-Хатангского регионального прогиба. Мезовал на западе примыкает к Притаймырскому мезовыступу и сформирован над серией контрастных положительных структур, сформированных над соляными куполами. Наличие соляного купола и связанного с ним поднятия доказано бурением на Нордвикской площади, расположенной в восточной части мезовала.

В структурном плане пермского структурного яруса Сопочный мезовал контролируется изогипсой -800 м, имеет площадь 1585 км$^{2}$ и осложнен четырьмя положительными структурами IV порядка. Расположенные в восточной части мезовала 
Нордвикское (№24) и Западно-Нордвикское (№23) локальные поднятия оконтурены на абсолютной глубине 400 м, имеют площади, соответственно, 200 и 95 км² и амплитуды 650 и 350 м. Купола, расположенные в западной части мезовала, незначительны по размерам и имеют площади 25-35 км².

K югу от Южно-Лаптевской синеклизы расположена вытянутая широтном направлении крупная надпорядковая полузамкнутая положительная структура Береговая гряда. Гряда, контролируемая изогипсой -800 м, имеет площадь 29055 км², протягивается вдоль береговой линии, наращивая с востока Сопочный мезовал и формируя единую вдольбереговую приподнятую зону. На востоке Береговая гряда «утыкается» в Верхоянскую складчатую область. В рельефе кровли перми гряда, имеющая амплитуду 750 м, осложнена двумя положительными структурам I порядка - Юрянгским и Пограничным мегавалами.

Расположенный в восточной части гряды Пограничный мегавал в структурном плане кровли перми контролируется изогипсой -650 м, имеет площадь 6490 км² и амплитуду 625 м. Мегавал осложнен Западно-Пограничным и Восточно-Пограничным мезовалами, которые вытянуты в широтном направлении и оконтурены изолиниями, проведенными на абсолютной глубине 600 м. Площади мезовалов составляют, соответственно, 3395 и 2055

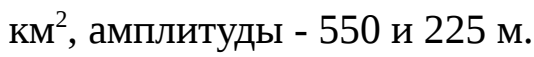

K северу от Пограничного мегавала намечается еще одна положительная структура (Приленское мезоподнятие), к югу расположен осложненный двумя замкнутыми депрессиями мезопрогиб, отделяющий Пограничный мегавал от Туоро-Хайского (УстьОленекского) мезовала.

Туоро-Хайский мезовал, контролируемый изогипсой -650 м, имеет площадь 1400 км², амплитуду 625 м, вытянут в широтном направлении и является зеркальным отражением расположенного на западе исследуемой территории Сопочного мезовала.

Мезовал также сформирован над контрастными положительными структурами, но не связанными с солянокупольной тектоникой. В рельефе кровли перми мезовал осложнен Усть-Оленекским и Нагымским валами, которые вытянуты в широтном направлении, контролируются изолиниями, проведенными на абсолютной глубине 600 м, имеют площади, соответственно, 575 и 750 км² и амплитуды 615 и 650 м.

K северу от Усть-Оленекского вала расположено Северо-Туорахское локальное поднятие (№31), к западу - Улахан-Юряхское куполовидное поднятие. Площадь СевероТуорахской структуры, контролируемой изогипсой -600 м, составляет 85 км², амплитуда $150 \mathrm{M}$. 
Улахан-Юряхское куполовидное поднятие, также оконтуренное на абсолютной глубине 600 м, изучено не только региональной, но и площадной сейсмикой 80-х годов. В рельефе кровли перми площадь структуры составляет 280 км², амплитуда - 550 м.

В западной части Береговой гряды, к западу от Пограничного мегавала расположен Юрянгский мегавал, который оконтурен на абсолютной глубине 700 м и осложнен тремя замкнутыми положительными структурами II порядка. Площадь мегавала составляет 10645 км² $^{2}$ амплитуда - 650 м.

Расположенное в центральной части Юрянгского мегавала Центрально-Юрянгское куполовидное мезоподнятие имеет изометричную форму и приурочено к выступу фундамента, который разделяет Сибирский и Лаптевоморский осадочные бассейны. Структура имеет изометричную форму, контролируется изолинией, проведенной на



В западной части Юрянгского мегавала расположен - Западно-Юрянгский вал вытянутая в северо-западном направлении положительная структура III порядка, осложненная тремя локальными поднятиями (№№19, 20, 26). В рельефе кровли перми

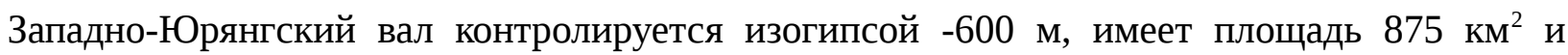
амплитуду 550 м. Осложняющие вал поднятия Верхнеюрянгское (№20) и Нижнеюрянгское (№26) контролируются изолиниями, проведенными на абсолютной глубине 550 м; площади структур составляют, соответственно, 330 и 215 км², амплитуды - 475 и 175 м.

В восточной части Юрянгского мегавала расположен Прончищевский вал, осложненный Прончищевским (№30), Северо-Прончищевским (№27) и Бастахским (№35) локальными поднятиями. Прончищевский вал вытянут в северо-восточном направлении, оконтурен изогипсой -575 м, имеет площадь 1195 км² и амплитуду 500 м. Расположенное в центральной части вала наиболее крупное Прончищевское локальное поднятие изучено площадной сейсморазведкой. Поднятие оконтурено на абсолютной глубине 400 м, имеет площадь 210 км² и амплитуду 325 м.

$\mathrm{K}$ югу от Береговой гряды и Сопочного мезовала расположена серия крупных депрессий - Енисей-Хатангский региональный прогиб, Юрянг-Хаянская и Таймылырская мегавпадины.

В западной части исследуемой территории, к югу от Сопочного мезовала расположен Енисей-Хатангский региональный прогиб, который в рельефе кровли перми ограничен на абсолютной глубине 1000 м, имеет в пределах исследуемой территории площадь 29100 км² $^{2}$ и амплитуду 2050 м.

Восточная часть Енисей-Хатанского регионального прогиба осложнена Хетским мегапрогибом, который также раскрывается в западном направлении за пределы 
исследуемой территории. Хетский мегапрогиб оконтурен на абсолютной глубине 1800 м,


Линейная депрессия осложнена тремя замкнутыми отрицательными структурами II-III порядка и одним Северо-Сандасским куполовидным поднятием. Северо-Сандасское поднятие имеет изометричную форму, оконтурено изолинией, проведенной на отметке -1800 м, и имеет площадь 310 км². Структура чрезвычайно контрастна, имеет амплитуду, превышающую 1000 м и, судя по характеру сейсмической записи, по аналогии с поднятиями Сопочного мезовала, сформирована над соляным куполом.

K востоку от Хетского мегапрогиба, в восточной части Енисей-Хатангского регионального прогиба получили развитие две отрицательные структуры - СевероКосистый прогиб, Западно-Угольная впадина и Косистое куполовидное поднятие.

Косистое куполовидное поднятие в структурном плане кровли перми контролируется

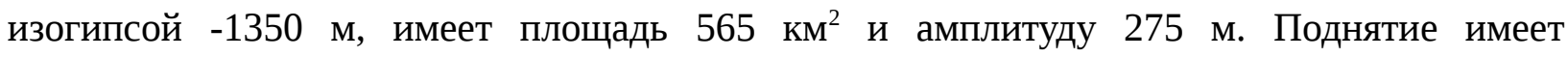
подковообразную форму и осложнено тремя куполами - Кожевниковским (№42), Ольгинским (№39) и Центрально-Ольгинским (№41).

Наиболее крупные Кожевниковское и Ольгинское локальные поднятия

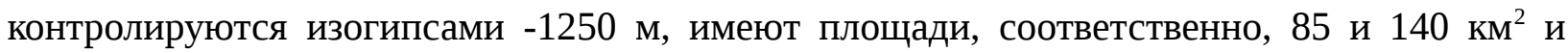
амплитуды 225 и 160 м. На абсолютной отметке -1300 м эти купола формируют единую вытянутую в северном направлении замкнутую положительную структуру Кожевниковское поднятие.

На Центрально-Ольгинской структуре в 2017 г. компанией Роснефть была пробурена скважина, которая привела к открытию одноименного месторождения. В рельефе кровли

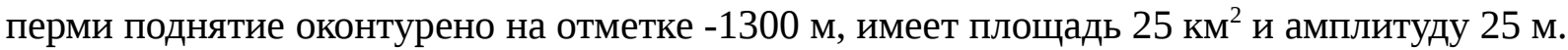

От Енисей-Хатангского регионального прогиба расположенная к востоку ЮрянгХаянская мегавпадина, осложняющая западную часть Лено-Анабарской синеклизы, отделена Западной мезоседловиной, в пределах которой расположен Тигяно-Анабарский вал, осложненный Чайдахским (№43), Гуримисским ((№34) и Восточно-Гуримисским (№40) локальными поднятиями. Тигяно-Анабарский вал вытянут в широтном


м. Осложняющие вал Гуримисское и Восточно-Гуримисское локальные поднятия ограничены на абсолютной глубине 500 м, имеют площади 305 и 255 км² и амплитуды 250 и 450 м.

Юрянг-Хаянская мегавпадина в рельефе кровли пермского структурного яруса




Депрессия несколько вытянута в широтном направлении и осложнена двумя замкнутыми отрицательными структурами II-III порядков.

В восточной части Лено-Анабарской синеклизы, расположена Таймылырская мегавпадина, которая отделена от Юрянг-Хаянской депрессии Восточной мезоседловиной, в пределах которой выделено два куполовидных поднятия №№17 и 19. Поднятия оконтурены на абсолютной отметке -800 м и осложнены локальными куполами. Площадь Седловинного куполовидного поднятия (№17) составляет 450 км², амплитуда - 175 м; Междуреченского (№19), соответственно, 75 км² и 260 м.

Расположенная к югу от Усть-Оленекского вала и Улахан-Юряской структуры Таймылырская мегавпадина в структурном плане кровли перми контролируется

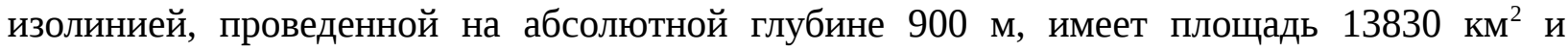
амплитуду 1350 м. На большей части депрессии выделяется полого погружающаяся в северном направлении моноклиналь и только вблизи Усть-Оленекского мезовала и УлаханЮряхского куполовидного поднятия фиксируется осевая, наиболее погруженная часть мегавпадины.

К югу от цепочки крупных депрессий, рассекающих исследуемую территорию в широтном направлении, получила развитие Северо-Анабарская мегамоноклиза, в пределах которой структурные планы всех опорных отражающих горизонтов регионально воздымаются в южном направлении.

В пределах мегамоноклизы, слабо изученной сейсморазведочными работами МОГТ, намечается серия крупных положительных структур, большая часть которых раскрывается за пределы исследуемого региона. В западной части мегамоноклизы выделены Новорыбинский и Друоханский мегавалы, на юго-востоке Оленекский свод, на большей части которого пермские отложения размыты.

На крайнем юго-востоке Хатанга-Ленского региона расположена северная часть Предверхоянского прогиба, в пределах которого пермь регионально погружается в направлении Верхоянской складчатой области.

Возвращаясь к характеристике структурных карт по неопротерозойско-мезозойским стратиграфическим уровням, еще подчеркнем, что рельефы этих поверхностей в значительно мере повторяют друг друга. При этом контрастность структурных планов и перепады глубин залегания горизонтов вверх по разрезу существенно падают (см. рис. 7).

Так, абсолютные отметки залегания кровли триас-юрского комплекса изменяются от -1400 до +600 м; кровля и подошва перми залегает в диапазонах -3600 - +800 и -4800 +500 м; кровля венда и рифея, соответственно, на отметках -6000 - +500 и -7000 - +500 м. 
Таким образом, от кровли юры к кровле рифея перепад отметок увеличивается более, чем в два раза.

\section{АНТИКЛИНАЛЬНЫЕ СТРУКТУРЫ - ЛОВУШКИ, СОЛЯНЫЕ КУПОЛА}

В Хатангско-Ленском междуречье выделяется два класса антиклинальных структур III-IV порядков, которые являются традиционными нефтегазоперспективными объектами во всех бассейнах мира:

- $\quad$ классические тектонические поднятия, сформированные в осадочном чехле над выступами фундамента;

- солянокупольные структуры, образовавшиеся в результате соляного тектогенеза.

Классические поднятия. В Анабаро-Хатангской НГО классические антиклинальные структуры, сформированные над выступами фундамента, выделяются на северо-востоке, на Западно-Юрянгском и Тигяно-Анабарском куполовидных поднятиях и в Западной мезоседловине, отделяющей Енисей-Хатанский региональный прогиб от ЛеноАнабарской синеклизы (рис. 9А).

В Лено-Анабарской НГО поднятия этого типа развиты только на севере. В этой зоне выделяется вытянутая в широтном направлении, вдоль береговой линии цепочка осложненных локальными положительных структур III порядка: Прончищевский мезовал, Улазхан-Юряхское мезоподнятие и Усть-Оленекский мезовал.

Анализ сейсмических разрезов позволяет сделать вывод о том, что на исследуемой территории классические антиклинальные структуры были сформированы, главным образом, в постюрское время, вероятнее всего, в позднем мелу и кайнозое. Об этом свидетельствуют следующие факторы:

- амплитуды поднятий практически не меняются от верхних горизонтов к нижним;

- мощности венд-мезозойских осадочных комплексов на структурах и в погруженных зонах практически не меняются;

- структуры осложнены разломами, секущими весь осадочный чехол.

Солянокупольные структуры. Связанные с соляными куполами поднятия расположены на севере Анабаро-Хатангской НГО, на северо-востоке Красноярского края и в Хатангском заливе моря Лаптевых (рис. 9Б).

В ИНГГ СО РАН было выполнено математическое моделирование процессов образования соляных диапиров в этом регионе НГО [Конторович В.А. и др., 2019а]. 
Результаты численных экспериментов, характеризующие стадии соляного тектогенеза, приведены на рис. 10.

Анализ результатов проведенных исследований позволил выделить следующие особенности соляных диапиров Анабаро-Хатангской НГО:

1. Незначительная ширина бассейна, в котором происходило накопление соленосных толщ, не дало возможности развиваться параллельным валам и растущим из них грядам куполов. В исследуемом районе была сформирована только одна гряда диапиров.

2. Большой дефицит плотности соленосной толщи по отношению ко всем перекрывающим породам привел к тому, что наиболее развитые соляные диапиры поднимаются на всю толщину разреза.

3. Значительная мощность отложений, перекрывающих соли, в сочетании с высокой плотностью подстилающих ее доломитов и ангидритов, обусловили рост диапиров в виде столбов, увенчанных грибообразной шляпкой - бульбой, расширяющейся по мере приближения к поверхности.

4. Высокая плотность карбонатных пород, залегающих на соленосной толще, способствовала дополнительному сжатию основания растущих куполов; особенностью зрелых куполов также является их трубообразная структура, с сердцевиной, выполненной субстратом подстилающих соли пород, поднимающимся, в ряде случаев, на всю высоту диапира.

Численные эксперименты показали, что в Анабаро-Хатанской НГО формирование наиболее контрастных соляных куполов началось в ранней перми и уже к началу триаса их амплитуды достигали 1000 м. К концу юры наиболее интенсивно растущие купола существенно прирастили амплитуды и сформировали классические грибообразные диапиры.

В мелу и кайнозое процесс роста основных куполов продолжался и одновременно произошла их трансформация в воронкообразные тела - в верхних частях куполов продолжали образовываться характерные карнизы, а в осевых частях шляпок диапиров формировались углубления. Основной рост менее контрастных погребенных куполов криптодиапиров, наиболее интенсивно происходил в позднем мелу и кайнозое.

\section{ДИСКУССИОННЫЕ ВОПРОСЫ}

На большинстве современных карт тектонического районирования в ХатангскоЛенском регионе выделяются два крупных внепорядковых тектонических элемента Анабаро-Хатанская седловина и Лено-Анабарский прогиб. В частности, эти структуры 
выделены на «Тектонической карте нефтегазоперспективных провинций Сибирской платформы» построенной в 2018 г. в $\mathrm{AO}$ «СНИИГГиМС» под редакцией В.С.Старосельцева.

В 30-х - первой половине 50-х гг. прошлого столетия исследуемая территория входила в состав единой Хатангской впадины, которая была выделена Н.С. Шатским в 1932 г. На тектонической карте СССР 1956 г. территория охватывающая современные Анабаро-Хатангскую седловину и Лено-Анабарский прогиб входили в состав Хатангского прогиба.

В работе 1959 г. М.К. Калинко вновь вернулся к термину Хатангская впадина, понимая под этой депрессией территорию, которая протягивалась от Янгодо-Горбитского поднятия на западе до низовьев левобережья р. Лены на востоке и охватывала исследуемый регион и восточные районы современного Енисей-Хатангского прогиба. В этой же работе в составе Хатангской впадины были выделены 3 крупных осложняющих ее структуры: Хетская синеклиза, Анабаро-Хатангская зона поднятий и Анабаро-Оленекский прогиб.

В последнее десятилетие серьезный цикл исследований по геологии и нефтегазоносности северо-востока Сибирской платформы и моря Лаптевых выполнил А.Ф. Сафронов (2011, 2015, Начальные геологические ресурсы... 2013)

На современных схемах тектонического строения северных районов Сибирской платформы Хетская синеклиза отнесена к Енисей-Хатангскому региональному прогибу, Анабаро-Хатангская зона поднятий трансформировалась в Анабаро-Хатангскую седловину, а Анабаро-Оленекский прогиб в Лено-Анабарский прогиб.

Анализ современных структурных построений показал, что Лено-Анабарский региональный прогиб несколько расширился на восток, но принципиальных изменений не претерпел. Этой структуре в рельефах верхнепроторезойско-фанерозойских осадочных комплексов отвечает крупная вытянутая в широтном направлении Лено-Анабарская синеклиза (суперпрогиб), осложненная двумя отрицательными структурами I порядка Юрянг-Хаянской и Таймалырской мегавпадинами.

Что касается западной части исследуемой территории, то Анабаро-Хатангская седловина в этой зоне не выделяется. Значительную часть Анабаро-Хатангского региона занимают две глубокие депрессии, разделенные Сопочным мезовалом. Южная депрессионная зона является восточным окончанием Енисей-Хатанского регионального прогиба, северная раскрывается в акваторию моря Лаптевых. Таким образом, тектоническое районирование этой территории требует уточнения и принятия согласованных решений. 
Полученные в процессе проведения исследований материалы могут служить надежной основой для уточнения схемы нефтегазогеологического районирования и количественной оценки ресурсов УВ Анабаро-Хатангской и Лено-Анабарской НГО ЛеноТунгусской НГП.

Работа выполнена в рамках программы фундаментальных научных исследований ИНГГ СО РАН (№ проекта в ИСГЗ Минобрнауки 0331-2019-0020) при финансовой поддержке РФФИ Ресурсы Арктики, проект 18-05-70105.

Литература

1. Афанасенков А.П., Никишин А.М., Унгер А.В., Бордунов С.И., Луговая О.В., Чикишев А.А., Яковишина Е.В. Тектоника и этапы геологической истории ЕнисейХатангского бассейна и сопряженного Таймырского орогена // Геотектоника. - 2016, № 2. C. 23-42.

2. Геология нефти и газа Сибирской платформы / Под ред. А. Э. Конторовича, В. С. Суркова, А. А. Трофимука. // М.: Недра, 1981. 552 с.

3. Граусман В.В. Геологический разрез Усть-Оленекской скв. 2370 (инт. 36052700) // Тихоокеанская геология. - 1995. Т. 14. - № 4. - С. 137-140.

4. Грамберг И.С. Геохимические исследования как один из методов поисков генетических признаков нефтематеринских толщ (на примере арктических районов СССР) / Нефтегазоносность севера Сибири. - 1958. - С. 171-182 (Тр. Института геологии Арктики, т. 92).

5. Калинко М.К. История геологического развития и перспективы нефтегазоносности Хатангской впадины // Л.: Гостоптехиздат, 1959. 360 с.

6. Каширцев В.А., Ким Н.С., Фурсенко Е.А., Дзюба О.С., Фомин А.Н., Чалая О.Н. Генезис нефтей и нефтепроявлений Анабаро-Хатангской седловины (Арктический сектор Сибирской платформы) // Литология, петрография, минералогия, геохимия. - 2013. - № 13. - С. 54 - 63.

7. Каширцев В.А. Органическая геохимия нафтидов востока Сибирской платформы // ЯФ Изд-ва СО РАН - Якутск. 2003. 160 с.

8. Конторович В.А., Конторович А.Э., Губин И.А., Зотеев А.М., Лапковский В.В., Малышев Н.А., Соловьев М.В., Фрадкин Г.С. Структурно-тектоническая характеристика и модель геологического строения неопротерозойско-фанерозойских отложений Анабаро-Ленской зоны // Геология и геофизика. - 2013. - Т. 54. - № 8. - С. 1253-1274. 
9. Конторович В.А., Беляев С.Ю., Конторович А.Э. Критерии классификации платформенных структур // Геология, геофизика и разработка нефтяных и газовых месторождений. - 2004. - № 1. - С. 47-58

10. Конторович В.А., Конторович А.Э., Мо.исеев С.А., Соловьев М.В. Структурно-тектоническая характеристика Лено-Анабарского региона // Геология нефти и газа. - 2014. - №1. - С. 74-82.

11. Конторович В.А., Калинин А.Ю., Калинина Л.М., Соловьев М.В. Сейсмогеологические модели и нефтегазоносность осадочных комплексов в арктических регионах Лено-Тунгусской нефтегазоносной провинции (Анабаро-Хатангская, ЛеноАнабарская нефтегазоносные области) // Геология нефти и газа. - 2019А. - № 5. - С. 15-26.

12. Конторович В.А., Лунёв Б.В., Лапковский В.В. Геолого-геофизическая характеристика Анабаро-Хатангской нефтегазоносной области; численное моделирование процессов формирования соляных куполов (Сибирский сектор Российской Арктики) // Геодинамика и тектонофизика. - 2019Б. - Т.10. -№2. - С.459-470.

13. Косыгин Ю.А. Типы соляных структур платформенных и геосинклинальных областей. // М.: АН СССР. 1960. 90 с.

14. Соляная тектоника Сибирской платформы. Под ред. Ю.А. Косыгина, Новосибирск: «Наука», Сибирское отделение. 1973. 162 с.

15. Старосельцев В.С., Дивина Т.А. Механизм девонского соленакопления на северо-западе Сибирской платформы // Геология и минерально-сырьевые ресурсы Сибири. - Новосибирск. - 2012. - № 2(10). - С. 88-95.

16. Старосельцев В.С. Тектоническое и нефтегазогеологическое районирование южного побережья и прилегающего шельфа моря Лаптевых // Геология и минеральносырьевые ресурсы Сибири. - 2012. - № 3(11). - С. 32-37.

А.Ф. Сафронов Модель строения пассивной континентальной окраины моря Лаптевых Горные ведомости, 2011, №6, С. 78-81.

Начальные геологические ресурсы углеводородов шельфа моря Лаптевых, Геология и геофизика, 2013, т.54, №8, А.Ф. Сафронов, Сивцев А.И., Чалая О.Н., Зуева И.Н., Соколов А.Н., Фрадкин Г.С.

Сафронов А.Ф. Некоторые проблемы освоения углеводородных ресурсов арктического сектора России, Экономика Востока России, 2015, № 02 (004), сентябрь, С. 21-25 


\section{Подписи к рисункам}

\section{Рис. 1. Схема геолого-геофизической изученности.}

1 - площади; 2 - береговая линия; 3 - административные границы; 4 - границы НГО, 5 - сейсмические профили МОГТ; глубокие скважины: 6 - вскрывшие фундамент, 7 - забой в рифее, 8 - забой в кембрии, 9 - забой в девонекарбоне, 10 - забой в перми.

\section{Рис. 2. Опорный разрез неопротерозойско-палеозойских отложений Анабаро-Хатангской НГО.}

1 - размывы и стратиграфические перерывы, 2 - базальты, 3 - туфы, 4 - аргиллиты, 5 - алевролиты, 6 - песчаники, 7 - угли, 8 - известняки, 9 - доломиты, 10 - известняки глинистые, 11 - мергели, 12 - соли, 13 - ангидриты, 14 брекчированные породы, 15 - гравелиты

Рис. 3. Опорный разрез верхнепротерозойско-палеозойских отложений Лено-Анабарской НГО.

1-2 - размывы и стратиграфические перерывы, 3 - аргиллиты, 4 - алевролиты, 5 - песчаники, 6 - известняки, 7 доломиты, 8 - ангидриты, 9 - гравелит.

Рис. 4. Сейсмогеологические разрез по композитным профилям Reg1, Reg_2 AXC-Л-A.

Рис. 5. Сейсмогеологическая характеристика кембрийских и вендских отложений ЛеноАнабарской НГО [Конторович, 2013].

Рис. 6. Сейсмические образы соляных куполов (диапиров) [Конторович, 2019Б].

Рис. 7. Структурные карты по кровлям перми (А), нижнего-среднего палеозоя (Б) и рифея (B).

1 - глубокие скважины, площади; 2 - береговая линия; 3 - Хатанга-Ленская (Усть-Оленекская) зона; 4 - населенные пункты; 5 - изогипсы; 6 - административная граница; 7 - зона отсутствия отложений; 8 - Верхоянская складчатая область.

\section{Рис. 8. Тектоническая карта арктических районов Сибирской платформы (Хатангско- Ленское междуречье).}

1- глубокие скважины, площади, 2 - береговая линия, 3 - реки, 4 - Хатанга-Ленская (Усть-Оленекская) зона, 5 населенные пункты, 6 - административная граница, 7 - зона отсутствия отложений перми, 8 - Верхоянская складчатая область; ТЕКТОНИЧЕСКИЕ ЭЛЕМЕНТЫ: положительные структуры: 9 - надпорядковые, 10 - I порядка, 11 - II порядка, 12 - III порядка, 13 - IV порядка; отрицательные: 14 - надпорядковые, 15 - I порядка, 16 - IIIII порядка; промежуточные структуры: 17 - моноклизы, 18 - моноклинали, 19 - мезоседловины.

Надпорядковые и 0 порядка: I - Восточно-Таймырская моноклиза, II - Южно-Лаптевская синеклиза, III Береговая гряда, IV - Енисей-Хатангский региональный прогиб, V - Лено-Анабарская синеклиза, VI- СевероАнабарская мегамоноклиза; VII - Предверхоянский региональный прогиб;

Положительные структуры: I порядка (мегавал, мегавыступ, свод): I - Притаймырский мегавыступ, II Юрянгский мегавал, III - Пограничный мегавал, IV - Новорыбинский мегавыступ, V - Друоханский мегавыступ, VI - Оленекский свод; II порядка (мезовал, мезоподнятие): 1 - Северо-Бегичевский, 2 - Приленское, 3- ЦентральноЮрянгское, 4 - Сопочный, 5- Западно-Пограничный, 6- Восточно- Пограничный, 7- Туора-Хайский (УстьОленекский); III порядка (куполовидное поднятие, вал): 1-Южно-Лаптевское-1, 2-Южно-Лаптевское-2, 3 Приленское поднятие, 4 - Восточно-Таймырское, 5 - Центрально-Береговое, 6 - Восточно-Оленекское, 7 - СевероОленекское, 8 - Северо-Хетский, 9 - Западно-Юрянгский, 10 - Прончищевский, 11 - Северо-Сандасское, 12 Косистое, 13 - Тигяно-Анабарский, 14 - Улахан-Юряхское, 15 - Усть-Оленекский, 16 - Нагымское, 17 Седловинное, 18 - Северо-Тюмятинский, 19 - Междуреченское, 20 - Центральнорыбинское, 21 - СевероДоруохское, 22 - Южное. 
Отрицательные структуры: I порядка (мегавпадина, мегапрогиб): I - Бегичевская, II - Хетский, III - ЮрянгХаянская, IV - Таймылырская. Мезоседловины: I-Западная, II-Восточная.

Рис. 9. Классические тектонические (А) и солянокупольные (Б) антиклинальные структуры.

Рис. 10. Эволюции солянокупольных структур Анабаро-Хатангской седловины [Конторович, 2019Б].

1 - границы слоев, 2 - соли, 3 - подстилающие соли карбонаты, 4 - время эволюции модели (геологический возраст). 
Таблица 1. Стратиграфическая приуроченность отражающих горизонтов

\begin{tabular}{|c|l|}
\hline $\begin{array}{c}\text { Индекс отражающего } \\
\text { горизонта }\end{array}$ & \multicolumn{1}{|c|}{ Стратиграфическая приуроченность } \\
\hline $\mathrm{K}_{0}-$ ? $\mathrm{T}_{0}$ & Подошва триаса \\
\hline $\mathrm{P}_{0}$ & Подошва перми / граница регионального эрозионного среза \\
\hline $\mathrm{PZ}_{0}$ & Подошва палеозоя/ кровля венда \\
\hline $\mathrm{RR}$ & Кровля рифея \\
\hline $\mathrm{R}_{1}-\mathrm{R}_{4}$ & Внутри рифея \\
\hline $\mathrm{R}_{0} / \mathrm{F}$ & Подошва платформенного рифея / кровля архея \\
\hline
\end{tabular}




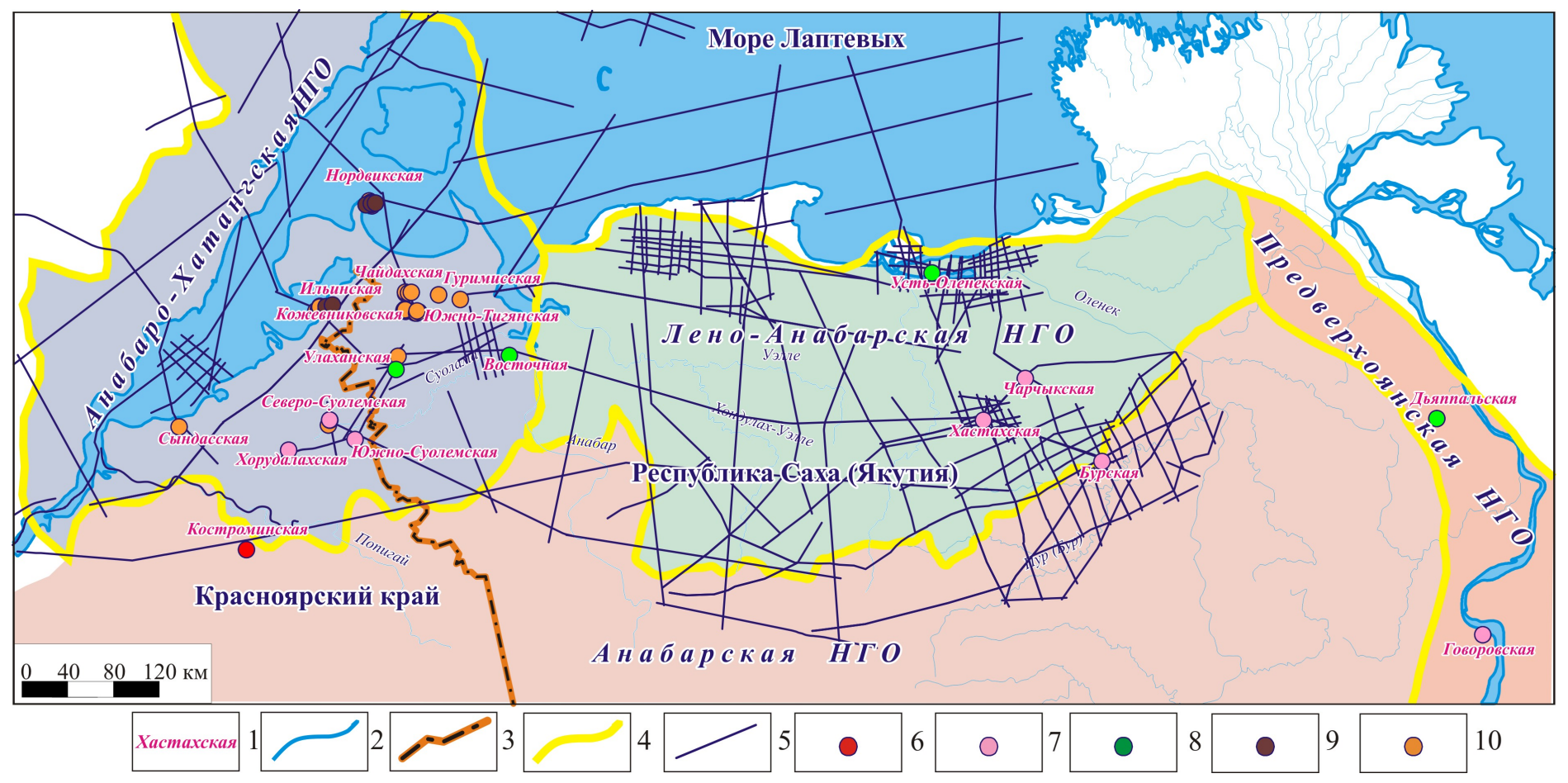




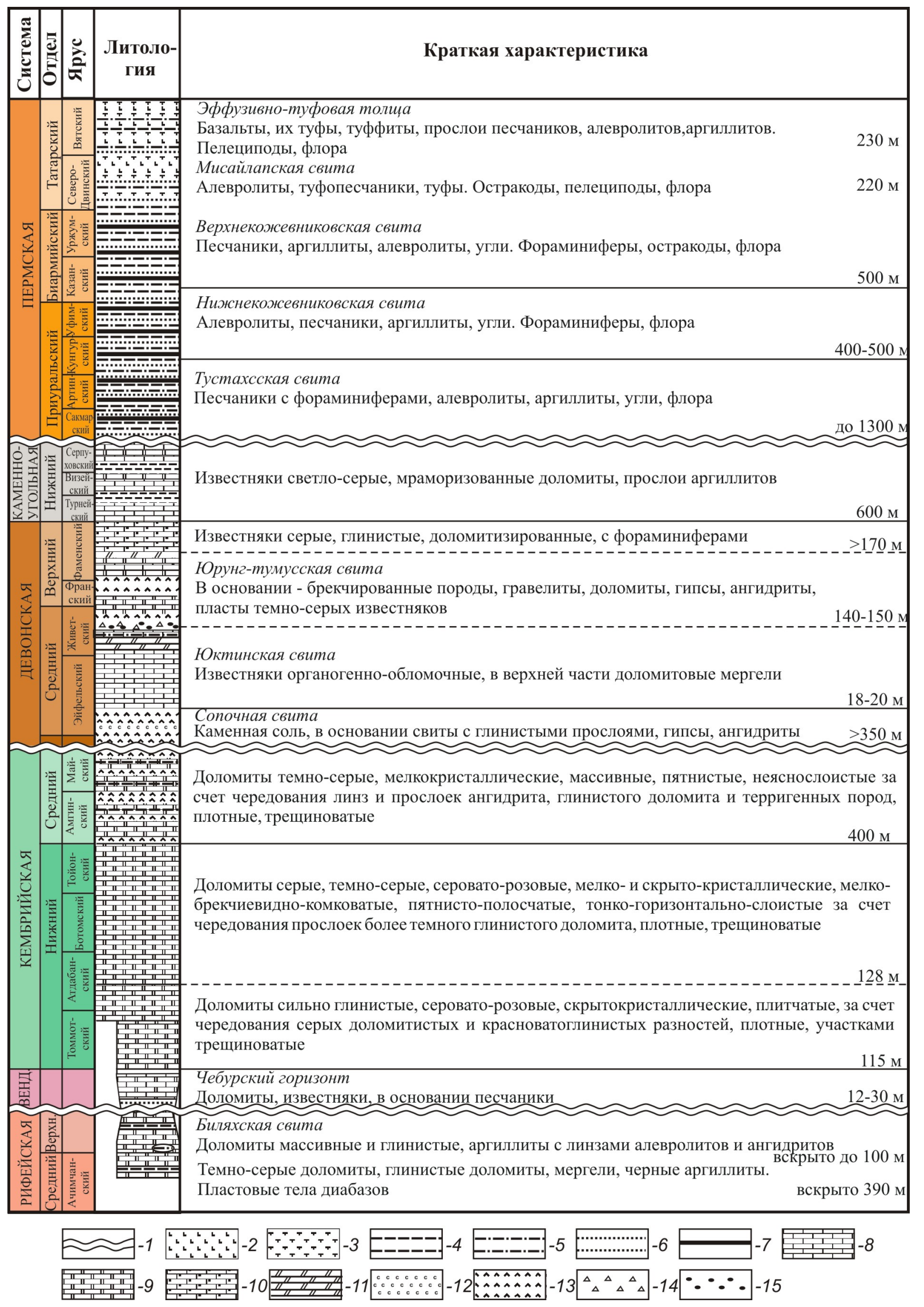






$\approx$ こ 







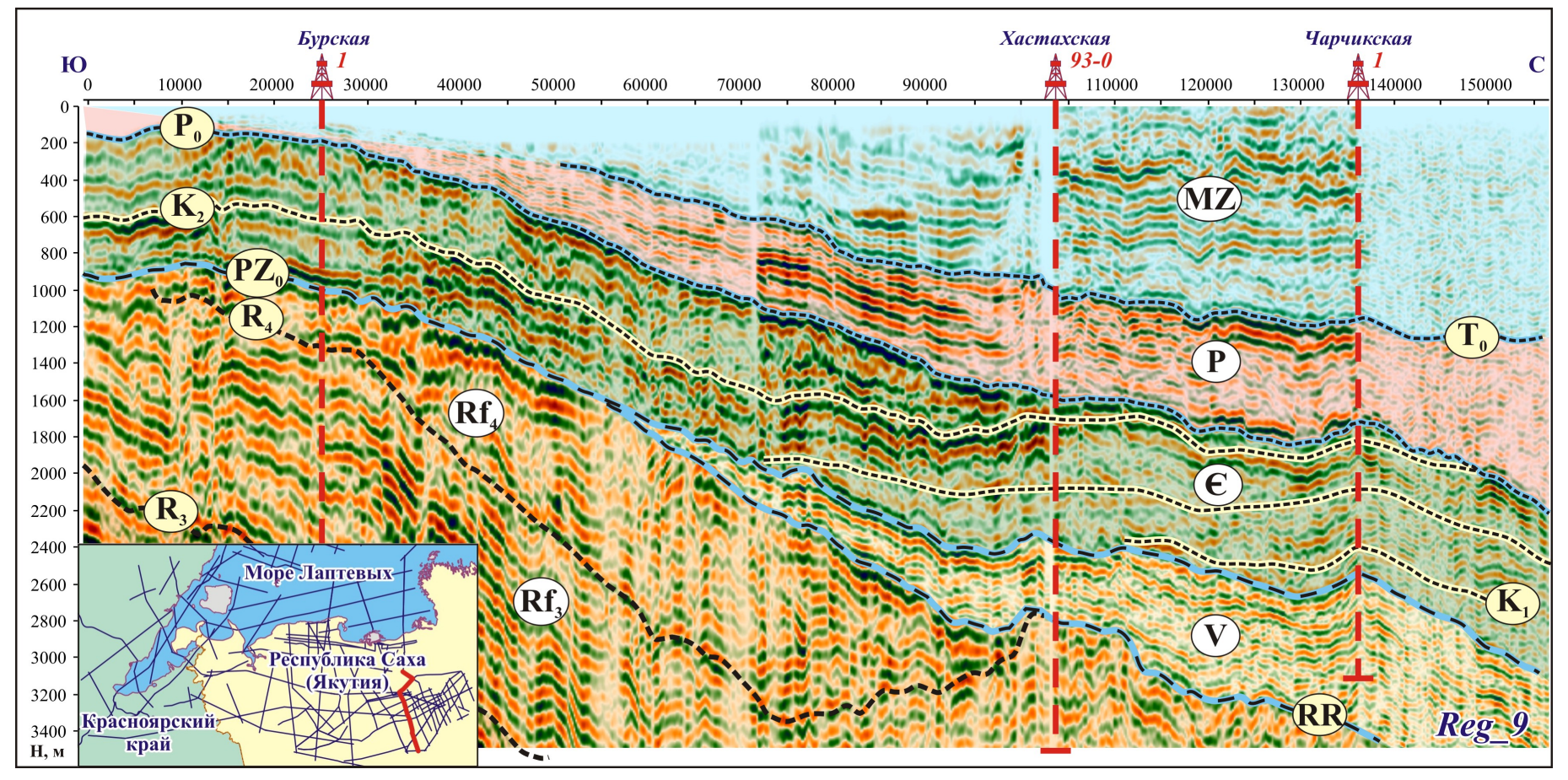









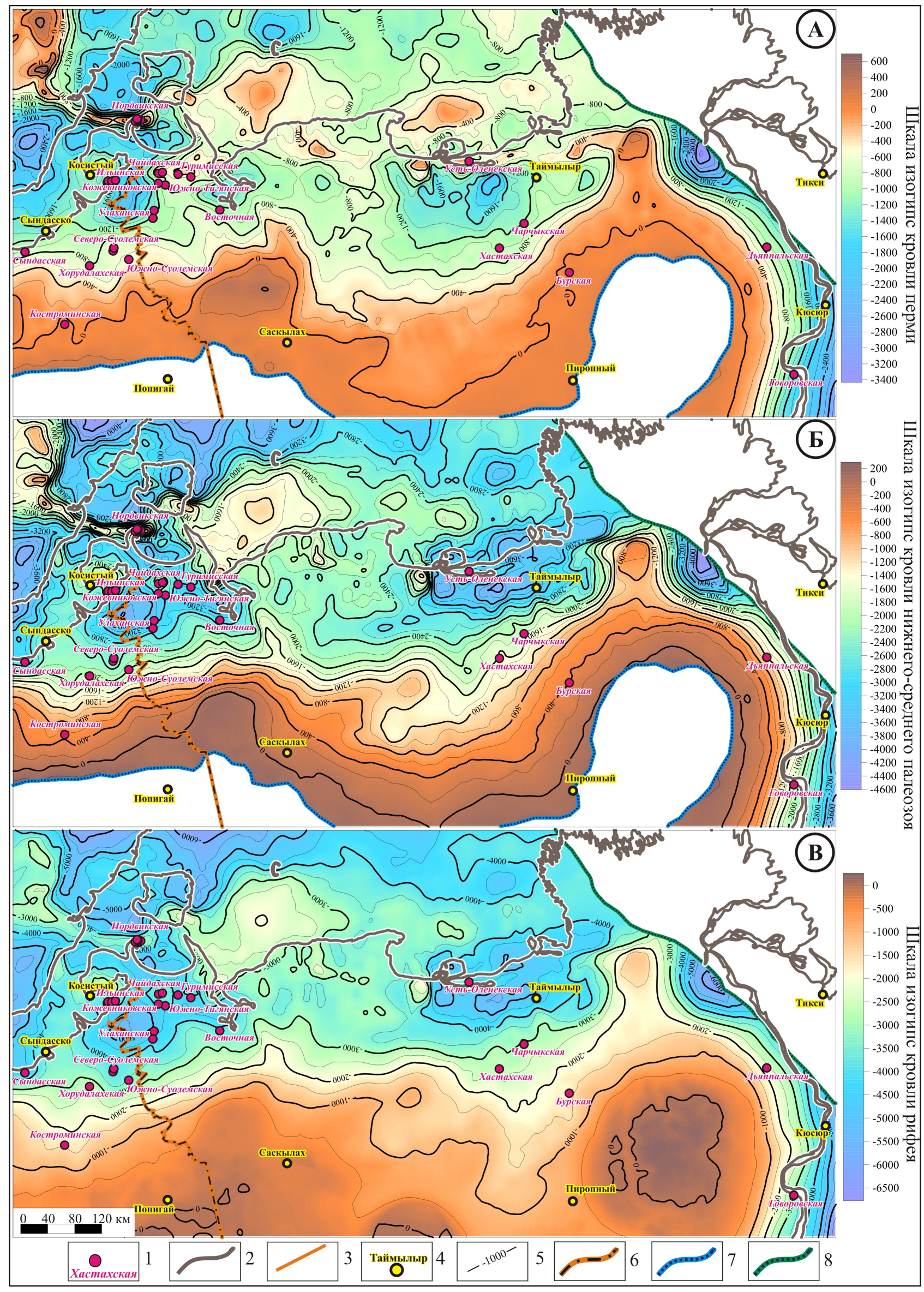




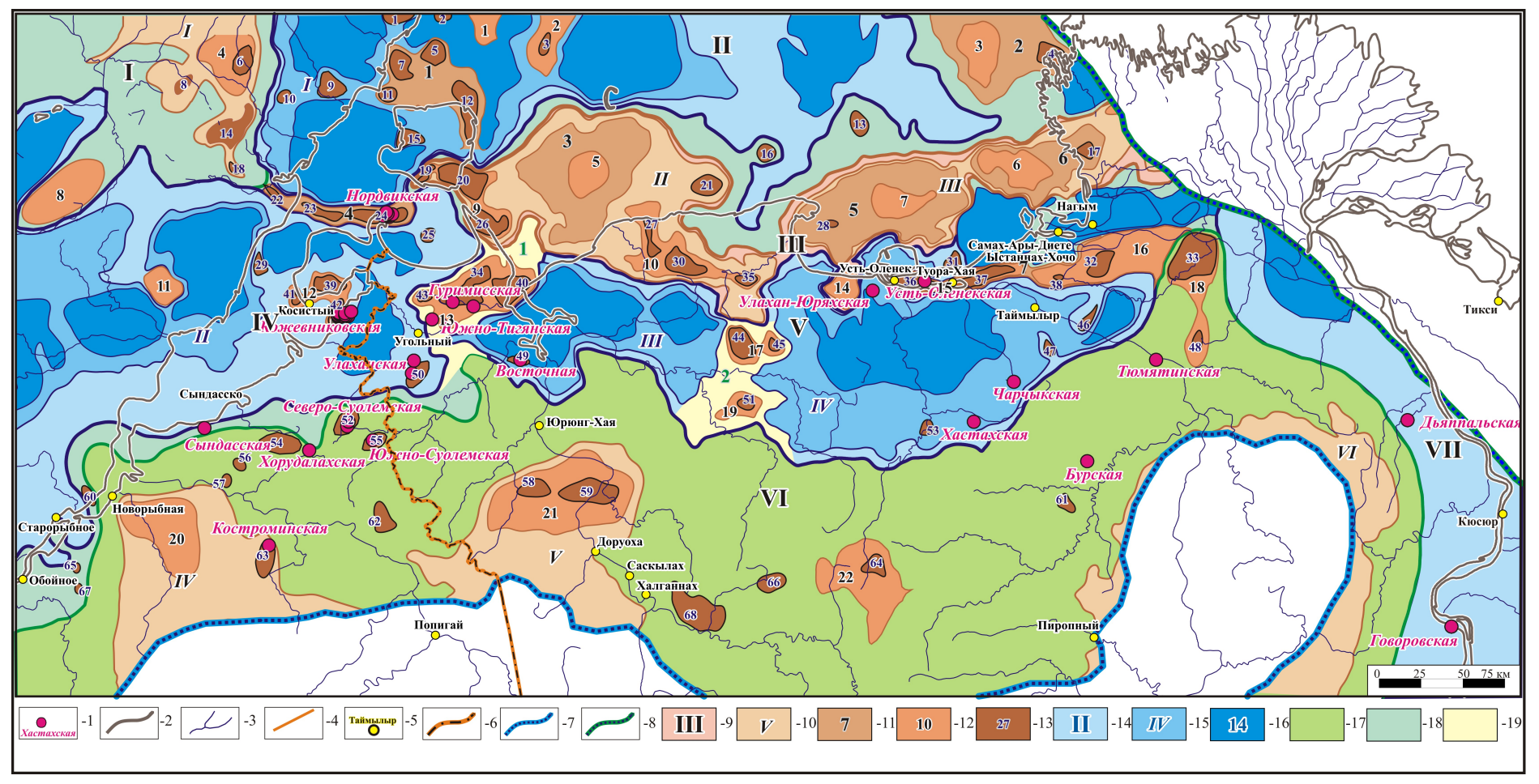



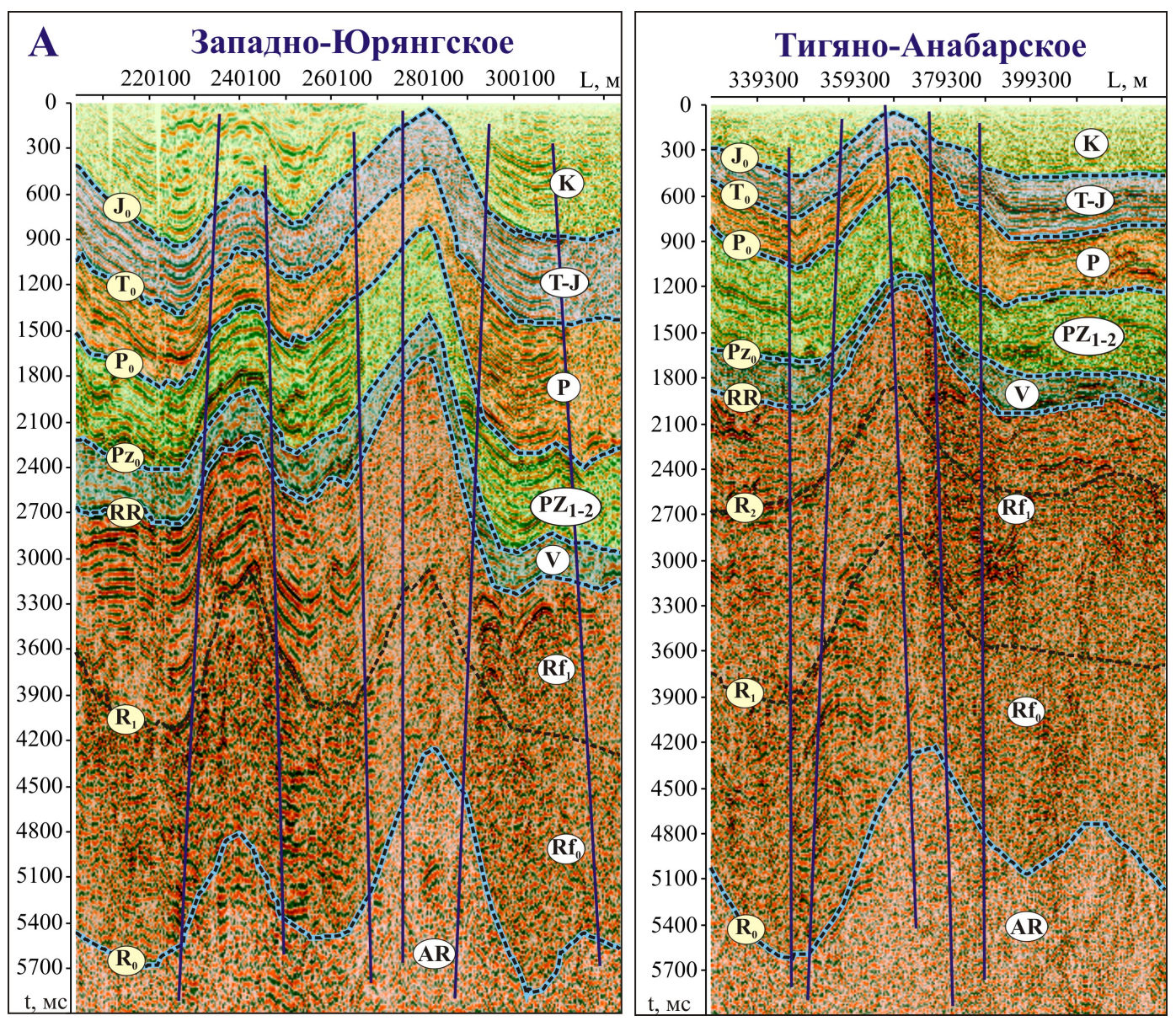


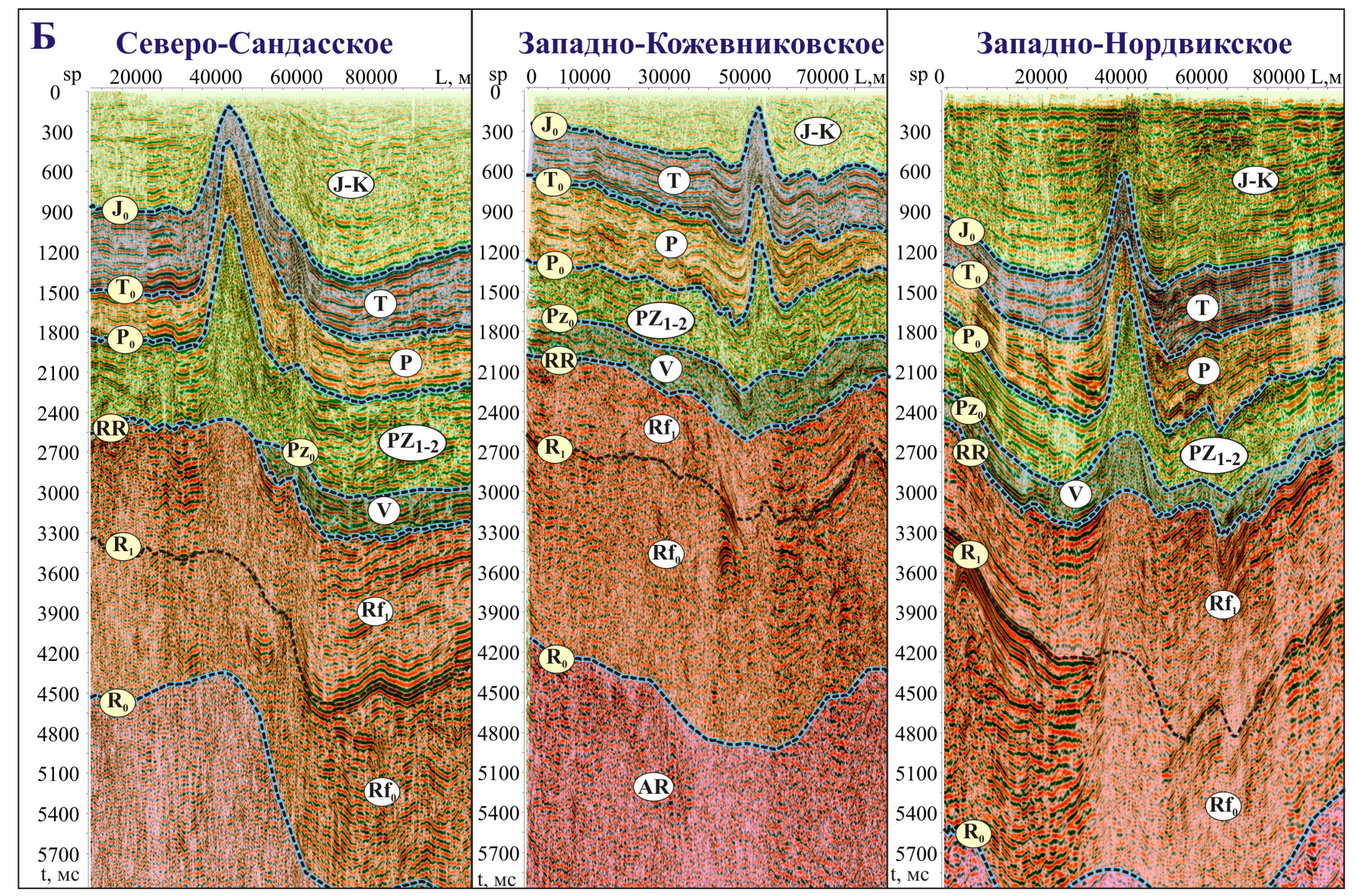




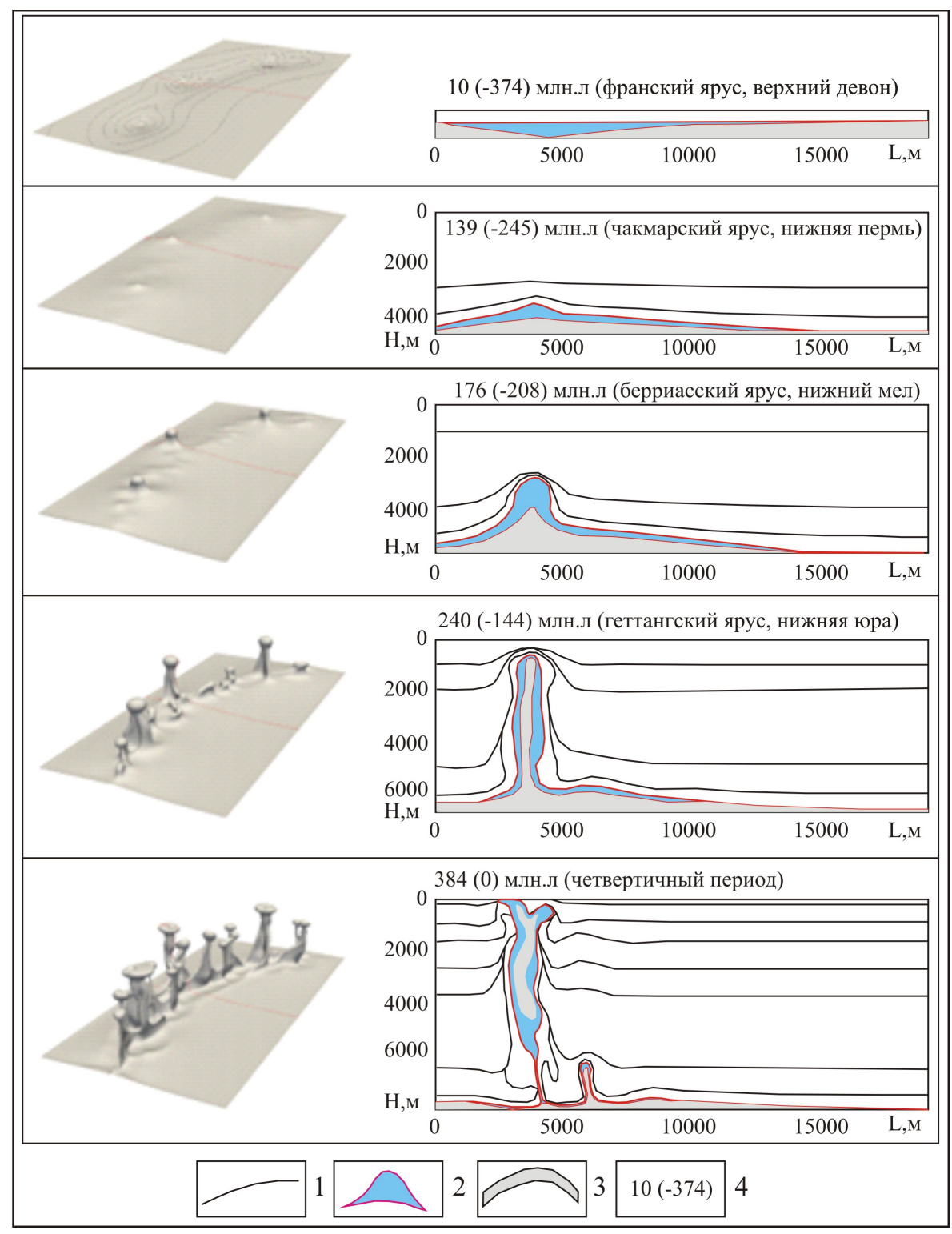

